\title{
International Criminal Justice in Africa: Some Emerging Dynamics
}

\author{
Lydia Apori Nkansah \\ Faculty of Law \\ Kwame Nkrumah University of Science and Technology \\ Private Mail Bag, University Post Office, Kumasi, Ghana, West Africa \\ Tel: 233-20-242-066 E-mail: ntowahaponk@yahoo.com
}

Received: March 4, 2011

Accepted: March 24, 2011

doi:10.5539/jpl.v4n2p74

\begin{abstract}
The phenomenon of using international criminal justice to address war crimes and human rights violations in conflict and post-conflict situations of Africa has emerged. This consist of a platform which is anchored in universal norms, with a court which does not form part of the domestic criminal system, and which in some cases sits outside the geographical jurisdiction of where the offences took place. The adjudicators may also be non-nationals. This paper examines the experiences regarding the enforcement of international criminal justice in Africa as instituted in the International Criminal Tribunal for Rwanda (ICTR) and the Special Court for Sierra Leone as well as in the framework of the International Criminal Court (ICC). It emerged that international criminal justice is meshed in politics and hence lacks the unflinching cooperation and support from the continent. The evidence as to its appropriateness for peace-building in conflict and post-conflict situations is mixed. The package offered by internationalized justice alienates both the adjudicators and the adjudicating society from the process, thereby denying the process with the impetus required for it to be beneficial to the end users. The implication of this study then is that the prospect of international justice in Africa is currently uncertain and its success would require concerted efforts by African governments, the African Union as a unified continental body and civil society organizations in collaboration with the international community.
\end{abstract}

Keywords: Civil conflicts, International Criminal Court, International criminal justice, Internationalized justice, Peace-building, Retributive justice

\section{Introduction}

Historically, the idea of retributive justice through prosecutions has existed for a very long time and has been considered as the most appropriate tool for addressing war crimes and past human rights abuses (Amnesty International, 2001; Vinjamuri, L. \& Snyder, J. 2004)). Thus, retributive justice is known to the respective legal systems of Africa and appears in national criminal codes. In recent times however, the idea of prosecuting and punishing individuals, based on a set of international norms with supposedly universal application, has emerged. Hitherto, states were the subjects of international law and hence individuals could not be held liable for crimes purportedly committed in breach of international law (Kittichaisaree, 2001). The belief was that the pursuit of international justice would prevent the reoccurrence of future abuses, provide retribution as a way for cleansing society of the evils, which were occasioned by the abuses, facilitates national reconciliation, and establish the truth of the abuses as well as serve as a catharsis for future prosecutions (Stensrud, 2009). In light of this, the international community then embarked on initiatives to prosecute alleged violations of international crimes and other heinous breaches of human rights in Africa. In Rwanda and Sierra Leone ad hoc war tribunals were set up to prosecute alleged perpetrators of war crimes. Similarly, the International Criminal Court (ICC), which is a permanent international body, has initiated proceedings into alleged abuses in some respective conflict situations of Africa (Ssenyonjo, 2007: Jacobs and Arajarvi, 2008).

The international criminal justice platform is anchored in universal norms, with judges and staff who may be foreigners. In addition, it consists of a court which does not form part of the domestic criminal system, and which in some cases sits outside the geographical jurisdiction of where the offences took place. Studies have been conducted into international criminal justice generally (Arzt, 2006): Fehl, 2004; Guibert \& Blumenstock, 2007; Holmes, 2002; Meernik, 2005) and in some cases into specific African situations (Apori-Nkansah, 2009; Dougherty, 2004; Evenson, 2004). It is however unclear what the benefits or the dynamics are, for using such a platform to administer justice in a post-conflict or conflict settings of Africa. The paper examines the role and experiences of international criminal 
justice in conflicts and post-conflict situations of Africa as well as the dynamics involved. This study provides important lessons, which could inform decisions in the area of international criminal justice in the future.

The study was anchored in the qualitative case study paradigm. Data consisted of documentary sources namely, statutes and relevant documents on the Courts/tribunals, reports of civil society organizations, statements and press releases and other secondary sources. These documents were collated, analyzed and reviewed to ascertain the nature of the experiences regarding the enforcement of the international criminal justice in Africa. The position of this paper is that firstly, international criminal justice is meshed up in politics and hence lacks the unflinching cooperation and support from the continent. Secondly, the evidence as to its appropriateness for peace-building in conflict and post-conflict situations is mixed. Thirdly, the package offered by internationalized justice alienates both the adjudicators and the adjudicating society from the process, thereby denying the process with the impetus required for it to benefit the end users. The prospect of international criminal justice would require concerted efforts by Africa governments, the African Union as a unified continental body, civil society organizations in collaboration with the international community. Again, the packaging - design and implementation should be adapted to the domestic settings of Africa.

\section{An Overview of International Criminal Justice and its Application in Africa}

The basic international frameworks that deal with the prosecution of war crimes or war related offences are international humanitarian law and international human rights law; both treaty and customary-based, and crimes against humanity jurisprudence (Bell, 2000).

International humanitarian law as encapsulated in the Geneva Conventions of 1949 (Conventions) with their 1977 protocols require State Parties to hold perpetrators accountable for "grave breaches" of the Conventions which occur in international conflicts within their territories. Alternatively, these states are required to hand over perpetrators to any of the contracting parties for accountability (Kittichaisaree, 2001). Article 50 of the Geneva Convention I defines "grave breaches" to include: "wilful killing, torture or inhuman treatment, including biological experiments, wilfully causing great suffering or serious injury to body or health, and extensive destruction and appropriation of property not justified by military necessity and carried out unlawfully and wantonly" and which are meted out "against persons or property protected by the Convention.” Further, Article 3 and Protocol II of the Geneva Conventions provide for individual accountability for breaches which are committed during internal armed conflicts.

International human rights law increasingly demands that State Parties punish certain human rights abuses. For example, Articles 1 and 5 of the Convention on the Prevention and Punishment of the Crimes of Genocide, 1948, demand for the protection, prevention and punishment for genocide. Similarly, Article 4 of the Convention against Torture and Other Cruel, Inhuman or Degrading Treatment or Punishment 1984, demands that all forms of torture should be criminalized. Others like the International Convention on Civil and Political Rights (ICCPR) (1966) though do not provide for punishment in themselves, yet failure to institute accountability measures for their enforcement by State Parties to the ICCPR will amount to failure to protect the rights enshrined in the ICCPR. It should be observed that some of the international conventions have assumed the status of customary international law due to their universal application; hence a nation's obligation to punish past abuses arises irrespective of the fact that it is not a party to such treaties (Bell, 2000).

The crimes against humanity jurisprudence emerged through the Nuremberg trials. It was incorporated in Article 6(3) of the Nuremberg Charter, 1945 that defined crimes against humanity as: "Murder, extermination, enslavement, deportation, and other inhuman acts committed against any civilian population ....or persecutions on political, racial or religious grounds". The concept of crimes against humanity has found expression in the Statutes of the ICTR, ICTY, ICC and the Special Court for Sierra Leone. It should be noted that in addition to the above, domestic criminal laws have been enforced by an international court (Statute of the Special Court for Sierra Leone, 2002). Basically, these set of norms regulate how war related offences are to be dealt with by states. Nevertheless, various channels for their enforcement have been used (Fehl, 2004; Apori-Nkansah, 2009).

In Africa, the African Union (AU) as a continental body has affirmed its commitment to "promote peace, security, and stability on the continent" and reserves the right to interfere in the member states regarding "war crimes, genocide and crimes against humanity"(Constitutive Act of the African Union, Article 4(h) ). The AU has also reiterated its support to the UN Security Council to decide to apply force in situations of "genocides, crimes against humanity, war crimes and ethnic cleansing" (The Ezulwini Consensus, 2005). Also, 43 African countries have signed up to the ICC framework with 30 ratifications, and the Republic of South Africa and Senegal have enacted laws to receive it domestically (Coalition for the International Criminal Court, 2009; Jalloh, 2009). Thus Several African governments have the obligation to deal with impunity on their shores by virtue of an international treaty or customary international law. 
It should be observed that the enforcement of international criminal justice in Africa has mainly been pursued through the mechanisms of ad hoc international tribunals namely the International Criminal Tribunal for Rwanda (ICTR) and the Special Court for Sierra Leone (known also as the Special Court) as well the International Criminal Court (ICC). A brief background into the establishment of these international courts is important as it provides readers with a fuller appreciation of the importance of these judicial bodies.

Even though there had been the desire of the international community to hold perpetrators accountable for heinous crimes, the Nuremberg and the Tokyo tribunals of 1945, which tried the German and Japanese war criminals for the abuses of the Second World War, marked the effective beginning of international criminal justice (Damrosch et al, 2001; O'shea, 2003 ). Due to the cold war, subsequent efforts by the UN to establish an international criminal tribunal in 1948, to prosecute genocide and other war crimes failed (Damrosch et al, 2001: Fehl, 2004). However, the massacre in the former Yugoslavia and Rwanda culminated in the establishment of the International Criminal Tribunal for the former Yugoslavia (ICTY) in 1992 and the ICTR in 1994 (Bogdan, 2008). The UN Security Council passed Resolution 955 in November 1994 to establish the ICTR. The ICTR was mandated to "prosecute persons responsible for serious violations of international humanitarian law committed in the territory of Rwanda and Rwandan citizens responsible for such violations committed in the territory of neighbouring States between 1 January 1994 and 31 December 1994" (Article 1, ICTR Statute). The ICTR was anchored in the UN administrative system, with international judges. This court was situated in Arusha, Tanzania, a city outside the geographical jurisdictions of where the offences it was to prosecute took place (ICTR Statute). The ICTR is presently still carrying out with its functions.

The Special Court for Sierra Leone came about after a violent civil conflict between the government of Sierra Leone and the Revolutionary United Front (RUF). The government requested assistance from the UN to establish a court to try members of the RUF. In the words of President Kabbah, the Court should "meet international standards for the trial of criminal cases, while at the same time, have a mandate to administer a blend of international and domestic Sierra Leonean Laws on Sierra Leonean soil” (Kabbah, 2000). Based on the request, the UN entered into an agreement with the government of Sierra Leone to establish the Special Court as an independent body outside the administrative system of the UN and Sierra Leone. The Special Court had the power "to prosecute persons who bear the greatest responsibility for serious violations of international humanitarian law and Sierra Leonean law committed in the territory of Sierra Leone since 30 November 1996, including those leaders who, in committing such crimes, have threatened the establishment of and implementation of the peace process in Sierra Leone" (Article 1 of the Statute of the Special Court). The Special Court was a hybridized domesticated international Court situated in Sierra Leone. The idea of the Special Court was meant to be an alternative to the ICTY and ICTR which were situated outside the geographical jurisdictions of where the offences they were to prosecute had taken place. It was aimed at bringing justice to the door steps of Sierra Leoneans in a cost effective way (Bigi, 2007; Doherty, 2004; Knowles, 2005; Stensrud, 2009).

The ICC is the outcome of the persistent efforts by the international community to have a criminal court with universal application (Fehl, 2004). Thus, following the massacre in the former Yugoslavia and Rwanda it renewed its earlier initiatives towards a permanent mechanism for the prosecution of war crimes. This culminated in the establishment of the ICC as a "permanent institution" to complement "national criminal jurisdictions". This approach by the international community was hinged on the belief that if perpetrators of war crimes had been pursued, postNuremberg impunity could have been averted. The ICC was vested with "the power to exercise its jurisdiction over persons for the most serious crimes of international concern" (Article 1 of the Rome Statute). These crimes included "the crime of genocide, crimes against humanity, war crimes and the crimes of aggression" (Article 5 of the Rome Statute). The seat of the ICC is at The Hague, although it could hold its sittings outside The Hague when it considers it necessary to do so (Article 3 of the Rome Statute). The ICC's indictments up to date are only in connection with alleged offences committed by Africans against Africans regarding conflict situations in Uganda, Sudan, Democratic Republic of Congo (DRC) and Central African Republic (CAR) (Jacobs and Arajarvi, 2008). The ICC is currently undertaking investigations into the conflict situation in the Republic of Kenya (ICC-01/09-1) and the Security Council has requested the ICC to investigate Libya for human rights abuses in the ongoing political upheavals in Libya.

\section{Emerging Dynamics}

\subsection{The Issue of Politics}

Even though African countries have been in support of the establishment and enforcement of international criminal justice, it appears international criminal justice is enmeshed in politics in Africa. When writing about the political nature of the ad hoc tribunals in Africa, O'Shea (2003) observed, "The ad hoc tribunals... are political creations" and "are not created out of a need for justice alone, but also for a political need and by virtue of political decision taken by 
politicians in political circumstances” (p.18). Cobban (2006) also maintained that the governments in power skewed the prosecutions to their advantage.

At the national fronts, international criminal justice has been evoked by some governments when they found it expedient to address domestic political exigencies. After the Rwandan government emerged a winner in an ethnic conflict it requested for the setting up of the ICTR to try perpetrators of war crimes. Cobban (2006) reported that:

The Rwandan government's control over most of the witnesses and physical evidence involved in the court's cases has given the government a huge bargaining chip. It has used its power to force the ICTR to halt its investigations into well-founded accusations that Kagame's supporters also committed atrocities (p. 28).

Similarly, the government of Sierra Leone which cooperated with the UN to set up the Special Court to try the RUF emerged a winner over the RUF through "political ruse and advantage” (O'Shea, 2003). The Sierra Leonean government requested for the support of the UN to set up a court to try the RUF. The Special Court although indicted pro-government actors, it is believed that this was done as a gesture to clothe the Court with impartiality. In reality the President used it to get rid of some of his political opponents and for revenge against the RUF (Apori-Nkansah, 2008).

After 20 years of a civil conflict between the government of Uganda and the Lord's Resistance Army (LRA), a rebel insurgency group in Northern Uganda, the Ugandan government requested the ICC to conduct an investigation into the abuses with the aim to prosecuting those responsible for the abuses when it could not quell the resistance. The ICC investigation resulted in the indictment of 5 LRA members. Being unable to achieve its desires as the indictees could not be arrested, the government blamed the ICC for its failure to capture the indictees and hence demanded the ICC to back off from Ugandan internal activities (Apori-Nkansah, 2008). Cobban (2006) maintained that the Ugandan government influenced the ICC's indictment in Uganda and succeeded in getting pro-government actors from being indicted by the ICC. It should also be pointed out that the DRC and CAR referred situations in their territories to the ICC (Jalloh, 2009).

Conversely, international criminal justice has been resisted by some African governments from coming to their territories where they found it would have direct effect on the rank and file of their government actors. Charles Taylor, as a sitting President of Liberia was protected by the West African sub-regional leadership and the international community when he was indicted for war crimes by the Special Court for Sierra Leone. Once it was clearly established that he was no longer President of Liberia, and peace had stabilised, the sub-regional leadership gave him up to the Special Court. Charles Taylor was indicted by the Special Court for Sierra Leone on March 3, 2003. The indictment was unsealed on June 4 with a warrant of arrest served on the Ghana Government that same day to arrest Taylor who was attending a peace talk in Accra, Ghana on the civil war in Liberia with the insurgency groups; the Liberian United for Reconciliation and Democracy (LURD) and the Movement for Democracy in Liberia (MODEL). The Ghanaian authorities refused to execute the international warrant for the arrest of Taylor (Bigi, 2007; Dougherty, 2004) on the basis that it would have been a dangerous precedent to arrest a sitting President and also America did not give them the go ahead to arrest Taylor (Kortuwah, 2003). America subsequently issued threats that Charles Taylor should step down as President of Liberia. Taylor resigned from office as president in August 11, 2003 and took asylum in Nigeria. David Crane, the first Prosecutor of the Special Court who indicted Taylor disclosed in an interview:

The international community was not ready to see this head of state, only the second in history behind Slobodan Milosevic, and the first African head of state to be indicted for war crimes at the international level, turned over to an international tribunal they created to prosecute those who bore the greatest responsibility for the atrocities that took place in Sierra Leone during the ten-year long civil war in the 1990’s. Scrambling, the United States, Great Britain, the United Nations, and Nigeria entered into an agreement to put Taylor aside in Calabar, Nigeria while a peace took hold in Liberia (Crane, 2006).

After Taylor had stepped down, the US Government passed a Bill in November, 2003 offering a reward of 2 million dollars for his capture. On March 17, 2006, Ellen Johnson-Sirleaf, the democratically elected government of Liberia, requested Charles Taylor be extradited to Liberia. Nigeria refused to extradite Taylor but agreed to release him. Taylor was reportedly missing from his residence but was apprehended by Nigerian authorities and handed over to the Special Court. Thus Taylor, as a sitting president was protected by the West African sub-regional leadership and the international community.

Similarly, the indictment of Omar al-Bashir, the Sudanese President by the ICC with the attendant issuance of the warrant of arrest had been met with strong resistance from the Sudanese government. The government of Sudan has refused to recognize the ICC on the basis that the ICC has no jurisdiction over Sudan because Sudan has not ratified the ICC framework (Machira, 2008). In consequence, al-Bashir threatened to rule out voluntary humanitarian assistance of NGOs to the detriment of the people of Darfur. The African Union is solidly behind al-Bashir in protest to his indictment of war crimes against the people of Darfur by the ICC. The ICC members States of Africa have 
accused the ICC of selective justice and "abuse of the principle of universal justice" and threatened their withdrawal from the ICC. The African Union has requested the UN Security Council to defer the process the ICC has initiated against al-Bashir in order to find peaceful settlement to the conflict situation in Darfur. Further, the African Union is poised to do "whatever is in its power to mobilize the necessary support" to halt the process against al-Bashir (PSC/PR/Comm9CLXXV; PSC/MIN/Comm.1 (CLI). At the international level, the Arab League has reiterated it support for al-Bashir, likewise China (Common Dreams, 2009), whilst United States of America stood aloof. Ironically the Liberian government which handed over Charles Taylor to the Special Court was in the forefront in the battle against the ICC for al-Bashir's indictment.

The foregoing evidence raises a number of issues regarding the political nature of the enforcement of international criminal justice in Africa. First, it seems that the receptability of international criminal justice is tied to the possibility of it being employed for political and other ends other than justice as the evidence from Rwanda, Sierra Leone and Uganda indicate. Existence of such opportunities might attract governments' support and cooperation for international criminal justice. This idea confirms similar findings made by Subotic, (2007), as to how international models for conflict resolution in the former Yugoslavia were used for other purposes. In this regard, Subotic reported that "under specific domestic conditions, states use the very tools designed to resolve conflict for very different political purposes, including getting rid of domestic political opponents, obtaining international financial aid, or ... as a proxy for admission to such prestigious international clubs".

Secondly, the issue of politics brings to the fore the dilemma being faced by the governments of Africa in keeping up with their international obligations. It appears that where insistence on prosecution could destabilize an already fragile situation, governments are reluctant to cooperate to enforce international criminal justice as was done in the case of Charles Taylor and al-Bashir. Thus once peace was stabilised in Liberia, Taylor was given up. This idea supports the assertion made by Vinjamuri (2001), that the decision to hold war criminals accountable and how to hold them accountable is linked to "broader strategic goals" of transitional policy. She maintained that in the view of policymakers, the values of "order and peace" are not coterminous. Therefore, where pursuit of justice will lead to instability they are not likely to support the setting up of an international tribunal to carry out prosecutions.

Thirdly, it could also mean that the governments signed up to the applicable treaties and the Rome Statute of the ICC in particular without giving due attention to its implications to the actions of their governments and their people. After all, the United States of America resisted the ICC idea on the basis of the protection of their citizens and worked around it to protect their soldiers from the jurisdiction of the ICC (Fehl, 2004). African leaders probably thought that as heads of states they enjoyed immunity and were protected from international prosecutions. Hence, they did not mind so long as indictments were towards their citizens and not to themselves as leaders of government. As a matter of fact Charles Taylor challenged his indictment on the basis of sovereign immunity (Prosecutor v Taylor, 2004, Appeal Chamber). But when the reality hit them (African leaders) that the situation will not be so, they closed their ranks to the international criminal justice to protect one another once the person remained part of the club of presidency on the continent. Thus Charles Taylor, as a sitting President was initially protected by the West African sub-regional leadership and al-Bashir is currently being shielded.

\subsection{International Criminal Justice and Peace-building}

The mandates of international criminal courts are clearly framed to try and punish perpetrators of war crimes and other perpetrators of heinous breaches of human rights in order to address these impunities and bring about national reconciliation. Thus one of the main goals cited for international criminal justice is that it "would contribute to the process of national reconciliation and to the restoration and maintenance of peace" (Cobban, 2006). Controversy however surrounds the perceived contribution of international criminal justice generally and specifically regarding its application as a peace-building tool to conflict and post-conflict situations (Akhavan, 2001; Feher, 1999; Meernik, 2005). It is important to point out that the mechanisms under considerations namely the ICTR, the Special Court and the ICC were invoked in respect of war related abuses. The societies of their intervention have been ravaged or were being ravaged by civil wars and the priority concern of these societies was being able to attain peace and stability (Berewa, 2001; Meernik, 2005).

In view of this, the pursuit of international justice in these war-torn countries is not an end in itself, but a tool or a strategy to facilitate peace-building. A Special Court official in an interview observed that the Special Court in Sierra Leone for instance should be measured by the extent to which it helped Sierra Leone to move forward from war to peace rather than how it has contributed to the jurisprudence of international criminal justice and the future of international law (Apori-Nkansah, 2008). This being the case, the issue that comes to the fore then is whether retribution can or does contribute to the dividend goal of peace and stability. Against this background, the evidence 
regarding the appropriateness of international criminal justice as a peace-building tool for national reconciliation is mixed and three paradigm cases emerged as discussed below.

The first paradigm consists of a situation where one of the warring factions emerged as the winner from the conflict, and the stronger party happened to be the government in power or the group that formed the government and cooperated with the international community to establish the Court. In this kind of situation, the indictment and arrest of alleged perpetrators did not appear to destabilize the peace process, but instilled fear in the populace and quelled impunity. However, there is no evidence suggesting that advancing retributive justice in this situation brought about national reconciliation, in places where this paradigm became applicable like the case of Sierra Leone (Apori-Nkansah, 2008; Cobban, 2006; Stensrud, 2009). The Special Court for Sierra Leone emerged in transitional contexts in which the government emerged a stronger force over the RUF (O'Shea, 2003). The indictments and arrests of members of the RUF, though created tensions did not destabilize the peace process. Conversely the Special Court did not bring about national reconciliation in Sierra Leone (International Crises Group as cited in Artzt, 2006). Similarly, Akhavan (2001) and Cobban (2006) reported that the ICTR did not bring about reconciliation in Rwanda.

As shown, where one emerged stronger to form government, international criminal justice could deal with impunity. This was possible probably because the government in charge which aided in the prosecution had control of the state security apparatus to support the venture as well as to quell any resistance. Alternatively, those who might not be in favour were weakened and were thus not in a position to put up any resistance. In Sierra Leone for example, the government requested for the setting up of the Special Court after it had arrested, Foday Sankoh, the leader of the RUF and some other high ranking members of the RUF.

The second paradigm refers to a situation where the conflict is ongoing and neither of the parties was able to subdue the other. In this kind of a scenario, the indictments and arrests of either side to the conflict aggravated the situation and in some cases created and distorted efforts to peacefully end the conflict. As already pointed out, after it was unable to quell the insurrection of the LRA the government of Uganda requested the ICC to intervene. This led to the indictment of some members of the LRA. The LRA response to the indictment was to brutally increase their attacks on civilians and aid workers (Allen, 2005; Cobban, 2006). The indictees could not be arrested and the government of Uganda then decided to grant amnesty to the members of the LRA and tried to get the ICC to withdraw the indictment as a condition to the negotiations. The ICC Prosecutor however refused to drop the indictments and ICC held on to the indictments while blaming the government for these developments. The government and its supporters on the other hand blamed the ICC for being a block to the peace process and the continuing blood shed in the Northern Uganda Apori-Nkansah, 2008; Cobban, 2006; Ssenyonjo, 2007).

As shown in the Darfur case, the indictment of al-Bashir, the Sudanese president worsened the peace process in that part of the country (Cobban; 2006 International Crisis Group, 2008 a). Consequently, the indictment of al-Bashir led to the sacking of UN forces, including the aid providers or humanitarian agencies. This was detrimental to the already vulnerable situation in Darfur. The peace-building process suffered a set back. In a similar incident, Charles Taylor abandoned a peace talk that was being hosted by the Economic Community of West African States (ECOWAS) on Liberia, when he was indicted by the Special Court (O,Shea, 2003).

With the second paradigm, where none emerged a winner or where the one in power is the one being pursued respectively, the application of international justice could give rise to undesirable complexities to the people in whose interest and for whose welfare justice was being invoked. In either of the cases, the attempt to bring some accountability was resisted. This should be of major concern to all the actors involved in the pursuit of international justice who have to take responsibility to protect those who are likely to be adversely affected by collateral damage under the circumstances. Prior investigations regarding collateral damage might be necessary to be undertaken by the UN, the ICC and other actors involved. To merely intervene and traumatize the already traumatized population in the name of universal norms however borders on irresponsibility.

The third paradigm deals with the nature of post-conflict societies and the rancour created by the trial of any alleged perpetrators in such societies irrespective of the political contexts of the transition. It should be pointed out that in a civil conflict the people have fought each other and the societies concerned are polarized, irrespective of the nature of the conflict. In these contexts prosecution is viewed by either side with suspicion when it goes against them no matter what. Again, deep seated rancour occurs where the notion and sentiments of the nationals concerning those who are perceived to be bad run counter to those considered as perpetrators who are indicted for alleged perpetration of offences (Apori-Nkansah, 2009).

The rancour and divisions generally created by international criminal justice may have also been fuelled by the fact that the larger portion of the populace are illiterates and political actors take advantage of the ignorance of the generality of the populace and incite them to their advantage. When this happens international criminal justice leads to 
undesirable consequences. In the observation of Subotic, (2007), "When transitional justice becomes "hijacked" for local political strategies, it can foster domestic backlash, deepen political instability, and even create alternative narratives of the past that can lead to further conflicts in the future”.

The analysis under this section shows the nature the of transitional contexts of post-conflict societies in Africa and how that impinge on international criminal justice and the fact that international criminal justice may not be expedient in all situations as an avenue for building peace for national reconciliation in the wake of an intricate local context of an internal armed conflict.

\subsection{The Issue of Internationalized Justice}

The package of international justice as pointed out is anchored in universal norms, with judges and staff who may be foreigners. In addition, it consists of a court which does not form part of the domestic criminal system, and which in some cases sits outside the geographical jurisdiction of where the offences took place. The internationalization of the process gave rise to certain dynamics which alienated the populace and in some cases the adjudicators from the processes thereby denying the processes with the impetus that should go with it.

Firstly, the notion of justice anchored in universal norms was found to be at variance with local norms and sentiments. For example, at the onset of the war in Sierra Leone, the country was divided into those who were good and those who were bad. The RUF and its allies were considered bad because they fought against Sierra Leoneans. Those who fought on the side of the government were considered good because they defended the populace. The mandate of the Special Court was to try those who bore the greatest responsibility for the offences which took place irrespective of which side of the war they fought. The Special Court indicted and tried Hinga Norman, the Coordinator of the Civil Defence Forces (CDF); a voluntary militia group. Norman died on February 22, 2007 in the custody of the Special Court. Sierra Leoneans were enraged by it because the CDF fought on the side of the government to defend their people and were considered heroes (Arzt, 2006). They registered their displeasure by voting out the government of Sierra Leone Peoples Party (SLPP), which collaborated with the UN to establish the Special Court and ushered in the government of All Peoples Congress (APC) whose protracted one party rule and bad governance supposedly brought about the civil war (Report of the Truth and Reconciliation Commission, 2004). This will impact on the political life of that country for a long period to come. Similarly, the people of Rwanda were dissatisfied with the outcome of the ICTR that they have resurrected gacaca, a traditional form of dispute resolution to address the aftermath of the conflict.

The above brings to the fore the prevailing socio-cultural conditions of the societies involved namely the people; who they are, their notion of justice, their feelings and sentiments about how the issues about the conflict should be handled. The challenge therefore remains as to how to get the populace to appreciate the value of justice as instituted by international criminal proceedings. A further research would be required in that regard.

Secondly, one of the main arguments in support of international criminal justice is that it provides an impartial justice, which is considered credible (Knowles, 2006). A salient element of impartiality is having unbiased adjudicators and top echelons of the Court/Tribunals who are non-nationals. It is thought that non-nationals add credibility and legitimacy to the proceedings. Thus, the ICTR had judges who were all foreigners and who did not speak the language of the Rwandans. The Special Court on the other hand was composed of national and non-nationals (Knowles, 2006), with the non- nationals in the majority. Out of the current eighteen Judges of the ICC only one judge (Ugandan) happens to be a national of one of the countries of the ICC's intervention (There is a judge from Kenya where ICC investigation is currently ongoing). The possibility of an indictee of the ICC being tried by a judge of the same nationality is therefore not high in view of the current composition.

The issue of foreign judges and staff gives rise to certain dynamics. There is the barrier of foreign judges in not understanding the social, cultural and language dynamics in which the alleged offences took place as well as their interpretation. Again, there is the lack of passion of foreign judges who are not in any way affected by the outcome of these trials to see that justice done. There is also the sense of betrayal that the accused persons feel when they stand in trial before foreigners. In Sierra Leone one of the indictees before the Special Court decried the situation of being judged by foreigners with the assertion that if he had offended his people they should sit in judgment over him but not hand him over to strangers (Apori-Nkansah, 2008).

Thirdly there is the issue of apathy towards the Courts/Tribunals. The setting up the mechanisms outside the country where the offences took place emerged as a factor. The ICTR was cited in Tanzania outside Rwanda. The Rwandans shrugged their shoulders when the ICTR was mentioned (Holmes, 2002). As a matter of fact Rwandans were indifferent toward the ICTR (Stove \& Weinstein as cited in Stensrud, 2009). The main reason cited for that is because it was situated in Arusha, Tanzania outside the shores of Rwanda so Rwandans did not have the physical access to it. Victims in particular "complained that they felt remote from the ICTR" (Doherty; 2004). In contrast to the indifferent attitude of the Rwandans, the Israelis were far away from Nuremberg but they were hooked to their radios to hear the 
trials of the Nazi criminals so even though the trials were not being undertaken in their country, they had the desire for revenge and to see justice done.

Even where the Special Court was cited in Freetown, the Sierra Leoneans were apathetic towards it and did not participate in the Special Court's proceedings. For instance, Sierra Leoneans considered the Special Court as a UN business (Apori-Nkansah, 2008). Moreover, the set up alienated the people from the process. In that they could not enter the Special Court premises freely as they could with the national Courts due to the requirements involved namely an ID Card and inspection. This resulted in apathy and mixed sentiments of the populace towards the Special Court. The indictment and arrest of Charles Taylor who was considered an enemy to Sierra Leoneans however was heralded by Sierra Leoneans. Even then they did not have the benefit of seeing him tried because the Special Court had to sit at The Hague for security reasons (Bigi, 2007). The ICC's proceedings were obviously detached from the communities in respect of whom the proceedings were being undertaken.

The internationalization of justice which resulted in the lack of passion on the side of the populace and the adjudication community seems to collaborate with the views of Holmes (2002), that the pursuit of international criminal justice should be "fuelled" by "revenge". Holmes maintained that in order for this to occur, those prosecuting and those adjudicating should believe that offences have been committed and that they should be addressed and punished. Likewise, this should be the resultant perception among members of the affected community. It is important for the affected community to have the desire to see that justice is done. Holmes argued that justice as an ideal is localized rather than universalized and thrives on emotion for its effectiveness. As the passion wanes, justice loses its meaning and offenders get less punishment. This probably confirms Kofi Annan the former UN Secretary-General's assertion that "No rule of law reform, justice construction, or transitional justice initiative imposed from the outside can hope to be successful or sustainable" (Report of the UN Secretary General on Transitional Justice and Rule of Law, 2004).

\section{Conclusion and the Way Forward}

Evidence from this study suggests that international criminal justice is meshed in politics. The study also revealed that retributive justice could possibly quell impunity occasioned by a protracted conflict particularly after it has ended and pockets of violence lingers here and there: but, it can neither end an ongoing conflict nor be an avenue for national reconciliation. Again, the internationalization of justice alienates both the adjudicators and the adjudicating society from the process, thereby denying the process with the impetus that it would require for it to benefit the end users or victims of war.

From the foregoing, it is being proposed that a conceptual framework for the enforcement of International criminal justice should ensure that Africans are in the fore front in the fight against impunity with the international community playing a complementary role. The paper therefore has implications for African governments, the African Union as a body, the African civil society groups in Africa, the United Nations and ICC.

The governments of Africa should live up to their responsibilities in keeping with world peace by dealing with impunity within their shores. This should commence with the passage of national legislation to admit universal norms into the national legal systems, as well as put measures in place for their enforcement. They should also cooperate with the international community in the event that national prosecutions are not feasible and international involvement becomes necessary.

The African Union should as a matter of urgency come out with policy guidelines for addressing impunity on the shores of Africa. Specifically it should come up with a strategic plan concerning how it intends to bring the crises in Darfur to an end as well as cooperate with the ICC to bring al-Bashir to some level accountability. It is not prudent to either request the UN for the suspension of the warrant of arrest on al-Bashir while pay lip service to the treaties they have signed up to.

The African civil society groups should be watchdogs over the rights of their respective communities and lead in demanding accountability from their government for their international obligation especially in cases that address impunity within their shores.

The international community and the UN as a body need to be sensitive to the domestic and national dynamics in their pursuit of international justice so as not to jeopardize the fragile peaceful equilibrium of those societies involved. Threats which are likely to emerge should be assessed and necessary protective measure put in place to curtail any undesirable consequences or foreseeable risks.

The package, design and implementation of mechanisms for international justice should take into consideration the people who are going to experience the processes and live with the effects of the mechanisms. In this regard, international packages should be adapted to the tradition and culture of the peoples and their communities. The ICC in 
particular should interpret its complementary roles along national efforts to broadly include interventions in varied forms beyond direct prosecution so as to be relevant to the African situation.

\section{References}

Allen, T. (2005). War and justice in Northern Uganda: An assessment of the International Criminal Court's intervention, An Independent Report.

Amnesty International (2001). Sierra Leone: Renewed commitment to end impunity. Al Index: AFR 51/007/2001.

Akhavan, P. (2001). Beyond impunity: can international criminal justice prevent future atrocities. American Journal of International Law, 95(1), 7-31. doi:10.2307/2642034, http://dx.doi.org/10.2307/2642034

Apori-Nkansah, L. (2009). The prosecution of war criminals by the Special Court for Sierra Leone within the arrangement of international criminal justice. GIMPA Journal of Leadership, Management and Administration, 5(2), 22-53.

Apori-Nkansah, L. (2008). Transitional Justice in Postconflict Contexts: The Case of Sierra Leone,s Dual Accountability Mechanisms: Published doctoral dissertation, Walden University, Minnesota, UMI, AAT 3291475

Arzt, D. E. (2006).Views on the Ground: The local perception of international tribunals in the former Yugoslavia and Sierra Leone. The ANNALS of the American Academy of Political and Social Science, 603(226), 226-239. doi:10.1177/0002716205281443, http://dx.doi.org/10.1177/0002716205281443

Berewa, S. (2001). Addressing Impunity Using Divergent Approaches: The Truth and Reconciliation Commission and the Special Court. In UNAMSIL (Ed.), Truth and Reconciliation in Sierra Leone, A compilation of Articles on the Sierra Leone Truth and Reconciliation Commission. David Williams Associates: Freetown. pp. 53-60

Bell, C. (2000). Peace agreements and human rights. Great Claredon: Oxford University Press.

Bigi, G. (2007). The decision of the Special Court for Sierra Leone to conduct the Charles Taylor Trial in The Hague. The Law and Practice of International Courts and Tribunals, 6, 303-316. doi:10.1163/156918507X217576, http://dx.doi.org/10.1163/156918507X217576

Bogdan, A, (2008). The United States and the International Criminal Court:Avoiding Jurisdiction Through Bilateral Agreements in Reliance on Article 98. International Criminal Law Review 8 1-54. doi:10.1163/156753608X265222, http://dx.doi.org/10.1163/156753608X265222

Coalition for the International Criminal Court (2009), Africa and the International Criminal Court, Retrieved September 22, 2009, from http://www.iccnow.org/documents/Africa_and_the_ICC.pdf

Cobban, H. (2006). International Courts. Foreign Policy, 153, 22-28.

Communique of the $175^{\text {th }}$ Meeting of the Peace and Security Council of the African Union (PSC/PR/Comm9CLXXV)

Communique of the 151 Meeting of the Peace and Security Council of the African Union (PSC/MIN/Comm1(CLI); Heinlein, 2009.

Common Dreams March 4, 2009 at Global Policy Forum, ICC Issues war crimes warrant for Sudan’s Bashir. [Online] Available: http://www.globalpolicy.org/component/content/article/164/28573.html (July 16, 2009)

David Crane, JURIST, $22^{\mathrm{ND}}$ March, (2006) [Online] Available: (http://jurist.law.pitt.edu/forumy/2006/03/handing-over-charles-taylor-its-time.php) ( March 1, 2010).

Damrosch, L.F., Henkin, L., Pugh, R.C., Schachter, O., and Smit, H. (2001). International Law: Cases and materials $\left(4^{\text {th }}\right.$ Ed). United States of America: West Group.

Doyle, N. (2004). Chile's process of recovery from human rights violence: Evaluating restorative and retributive approaches. Unpublished master's thesis. Dalhousie University. Halifax, Nova Scotia.

Dougherty, B.K. (2004). Right-sizing international criminal justice the hybrid experiment at the Special Court for Sierra Leone. International Affairs, 80(2), 211-328. doi:10.1111/j.1468-2346.2004.00385.x, http://dx.doi.org/10.1111/j.1468-2346.2004.00385.x

Evenson, E. M. (2004). Truth and Justice in Sierra Leone: Coordination between commission and court. Columbia Law Review.104 (3), 730-768. doi:10.2307/4099329, http://dx.doi.org/10.2307/4099329

Fehl, C. (2004). Explaining the International Criminal Court: A 'Practice Test' for rationalist and constructivist approaches. European Journal of International Relations, 10(357), 357-394. doi:10.1177/1354066104045541, http://dx.doi.org/10.1177/1354066104045541 
Feher, M. (1999). Terms of reconciliation, in Hesse, C. \&Pos, R., eds, Human Rights in Political Transitions: Gettyburg to Bosnia. New York: Zone, pp. 325-338.

Guibert, N. \& Blumenstock, T. (2007). The first judgment of the Special Court for Sierra Leone: A missed opportunity? The Law and Practice of International Courts and Tribunals, 6, 367-39. doi:10.1163/156918507X268075, http://dx.doi.org/10.1163/156918507X268075

Harper, E. (2005). Delivering Justice in the wake of mass violence: New approaches to transitional justice. Journal of Conflict and Security Law, 10(2), 149-185. doi:10.1093/jcsl/kri013, http://dx.doi.org/10.1093/jcsl/kri013

Holmes, S. (2002). Why International Justice Limps. Social Research, 69(4), 1055-1077.

International Criminal Court (2009) on Structure of the ICC. [Online] Available: http://www.icc-cpi.int/Menus/ICC/Structure+of+the+Court/ (July 9, 2009)

Jacobs, D. and Arajarvi, N. (2008). The International Criminal Court. The Law and Practice of International Courts and Tribunals, 7, 115-116. doi:10.1163/157180308X332748, http://dx.doi.org/10.1163/157180308X332748

Jalloh, C.C. (2009). Regionalizing International Law Review. International Criminal Law Review, 9, 445-449. doi:10.1163/157181209X457956, http://dx.doi.org/10.1163/157181209X457956

Kittichaisaree K. (2001). International Criminal Law, Oxford New York: Oxford University Press.

Knowles, P. (2006).The Power to Prosecute: the Special Court for Sierra Leone from a defence perspective. International Criminal Law Review, 6, 387-417. doi:10.1163/157181206778553860, http://dx.doi.org/10.1163/157181206778553860

Kortuwah, P. Liberia Betrayed Again, The Perspective, Atlanta, Georgia, September 3, 2003

Letter of President Tejan Kabbah addressed to the UN Secretary General requesting for the assistance of the UN to prosecute the RUF. Dated, June 12, 2000.

Meernik, J. (2005). Justice and peace? How the international criminal tribunals affects societal peace in Bosnia. Journal of Peace Research, 42, 271-289. doi:10.1177/0022343305052012, http://dx.doi.org/10.1177/0022343305052012

O'shea, A. (2003). Ad hoc tribunals in Africa: A wealth of experience but a scarcity of funds. African Security Review, 12(4), 17-24.

President of ICC's decision assigning the situation in the Republic of Uganda to Pre-Trial Chambers II. ICC-01/09-[Online] Available: http://www.icc-cpi.int/iccdocs/doc/doc778243.pdf1 (December 13, 2010)

Prosecutor v. Taylor. Case NO SCSL-03-01-I-059(Special Court for Sierra Leone, May 31, 2004). [Online] Available: http://www.sc-sl.org/LinkClick.aspx?fileticket=7OeBn4RulEg=\&tabid=191 (March 8, 2010)

Report of the Truth and Reconciliation Commission of Sierra Leone (2004) [Online] Available: http://www.trcsierraleone.org/drwebsite/publish/index.shtml(July 10, 2006)

Report of the United Nations Secretary-General on the rule of law and transitional justice in conflict and post-conflict societies, 2004, S/2004/616.

Rome Statute of the International Criminal Court. [Online] Available: http://untreaty.un.org/cod/icc/statute/english/rome_statute\%28e\%29.pdf (March 24, 2011)

Ssenyonjo, M. (2007). The International Criminal Court and the Lords Resistance Army Leaders: Prosecution or Amnesty. International Criminal Law Review, 7, 361-389. doi:10.1163/156753607X204266, http://dx.doi.org/10.1163/156753607X204266

Statute of the International Criminal Tribunal for Rwanda[Online] Available: http://www.un.org/ictr/statute.html((July 2009)

Statute of the Special Court for Sierra Leone (2002). [Online] Available: http://www.sc-sl.org/documents.html (May 3, 2007)

Stensrud, E.E. (2009). New dilemmas in transitional justice: Lessons from the mixed courts in Sierra Leone and Cambodia. Journal of Peace Research, 46(5), 5-15. doi:10.1177/0022343308096152, http://dx.doi.org/10.1177/0022343308096152

Subotic, J. (2007). Hijacked justice: Domestic use of International Norms. Doctoral Dissertation, The University of Wisconsin - Madison, Minnesota. 
Teitel, R. (1999).Bringing the Messiah through the law, in Hesse, C. \&Pos, R., eds, Human Rights in Political Transitions: Gettyburg to Bosnia. New York: Zone 177-194.

The Common African Position on the Proposed Reform of the United Nations: The Ezulwini Consensus, 2005, ext/Ex.CL/2 (VII).

Vinjamuri, L. (2001) Trading order for justice? : Prosecuting War Criminals in the Aftermath of Conflict. Doctoral Dissertation, Columbia University, New York

Vinjamuri, L. \& Snyder, J. (2004). Advocacy and scholarship in the study of international war crime tribunals and transitional justice. Annual Review of Political Science, 7(1), 345-362. doi:10.1146/annurev.polisci.7.012003.104755, http://dx.doi.org/10.1146/annurev.polisci.7.012003.104755 